Вісник Дніпропетровського університету. Біологія. Екологія. - 2008. - Вип. 16, т. 2. - С. 60-64. Visnyk of Dnipropetrovsk University. Biology. Ecology. - 2008. - Vol. 16, N 2. - P. 60-64.

УДК УДК 546.719+577.352.3+612.111

В. В. Івчук, Н. І. Штеменко

Дніпропетровський національний університет ім. Олеся Гончара

\title{
ФУНКЦІОНАЛЬНА АКТИВНІСТЬ ГЕПАТОЦИТІВ ЩУРІВ ПРИ КАНЦЕРОГЕНЕЗІ
}

\begin{abstract}
Вивчено рівень ферментативної активності гепатоцитів щурів за розвитку карциноми Герена, а також за введення сполук ренію та цис-платину. Встановлено, що за одночасного введення цисплатину з кластерними сполуками ренію у ліпосомній формі спостерігалось зниження ферментативної активності до рівня контрольної групи тварин, що свідчить про можливі гепатопротекторні властивості сполук ренію.
\end{abstract}

V. V. Ivchuk, N. I. Shtemenko

Oles' Gonchar Dnipropetrovsk National University

\section{FUNCTIONAL ACTIVITY OF THE RATS' HEPATOCYTES UNDER CANCEROGENESIS}

Enzymatic activity in rat's hepatocytes under carcinoma Geuren T8 development as well as after introduction of rhenium compounds and cis-platin were studied. It has been determined that the decrease of enzymatic activity contrary to the control animals has been observed under simultaneous injection of cisplatin and cluster rhenium compounds in a liposome form. That confirms possible hepatoprotective properties of the rhenium compounds.

\section{Вступ}

Печінка - орган, у якому за цитостатичної терапії метаболізується більшість цитостатиків [8; 12]. Протипухлинні препарати не мають специфічного впливу, тому кожний із них має великий спектр побічних ефектів $[5 ; 7 ; 11 ; 13-15]$. Більшість протипухлинних препаратів володіють гепатотоксичністю $[7 ; 9 ; 10 ; 14]$. Цис-платин - ефективний протипухлинний препарат, що використовується в онкологічній практиці. Однак відомо, що разом із високою ефективністю цей препарат володіє цитотоксичною дією на нормальні тканини печінки [9; 13]. Клініко-морфологічні ураження печінки за цитостатичної терапії супроводжуються гепатопатіями, токсичними гепатитами, цирозами печінки. Потенціальні нейтралізатори токсичних впливів протипухлинних препаратів, по-перше, не повинні стимулювати ріст та метастазування злоякісних пухлин i, подруге, не повинні знижувати ефективність протипухлинних препаратів.

У наших попередніх працях $[1 ; 3 ; 6 ; 16]$ показано, що кластерні сполуки ренію проявляють антирадикальну, антигемолітичну активність у моделях in vitro та in vivo та $\epsilon$ біохімічними модуляторами цис-платину, тобто підсилюють його дію з одночасним зниженням токсичності. У цих працях поряд із протипухлинними властивостями вивчали вплив сполук ренію на стан системи червоної крові, залишаючи стан печінки тварин поза розглядом. Також нез'ясованим питанням у цьому напрямку досліджень $\epsilon$ використання ліпосомних форм та роль органічних радикалів, що оточують кластер-

(C) В. В. Івчук, Н. І. Штеменко, 2008

60 
ний фрагмент $R e-R e$. Мета даної роботи - проаналізувати дію двох кластерних сполук ренію з різними лігандами, а також їх ліпосомних форм на показники ферментативної активності ферментів - маркерів цитолізу гепатоцитів: аспартатамінотрансферази $(\mathrm{AcAT})$, аланінамінотрансферази (АлАТ), лактатдегідрогенази (ЛДГ) у гомогенаті тканин печінки щурів із карциномою Герена на фоні введення цис-платину.

\section{Матеріал і методи досліджень}

Дослідження проводили на білих безпорідних щурах масою тіла 100-150 г. Суспензія клітин карциноми Герена $T 8$ (30 \% у фізіологічному розчині) перещеплювалася здоровим щурам від пухлиноносіїв, отриманих в Інституті експериментальної патології, онкології та радіобіології ім. Р. Є. Кавецького НАН України. Тварин поділено на групи: 1 - інтактні тварини; 2 - щури, яким трансплантували карциному Герена; 3 щури-пухлиноносії, яким вводили цис-платин за схемою [17]; 4 - щури-пухлиноносії, яким вводили цис-платин та $\left[\mathrm{Re}_{2}\left(\mathrm{CH}_{3} \mathrm{COO}\right)_{4}\left(\mathrm{H}_{2} \mathrm{PO}_{4}\right)_{2}\right] \cdot 2 \mathrm{H}_{2} \mathrm{O} ; 5$ - щури-пухлиноносії, яким вводили цис-платин та ліпосомну форму $\mathrm{Re}_{2}\left(\mathrm{i}-\mathrm{C}_{3} \mathrm{H}_{7} \mathrm{COO}\right)_{4} \mathrm{Cl}_{2}$. Ліпосомні форми сполук ренію готували за методикою [16].

Тварин декапітували на 21-у добу після трансплантації пухлин. Частину тканин печінки відбирали для гістологічних досліджень і фіксували у $10 \%$ розчині нейтрального формаліну. Вирізали зразки тканин печінки товщиною 3-5 мм. Зразки зневоднювали у спиртах зростаючої концентрації (70-100\%), заливали у парафін і готували на мікротомі зрізи товщиною 5-7 мкм. Гістологічні зрізи фарбували гематоксиліном і еозином та за Ван-Гізоном [2].

Гомогенат тканин печінки отримували шляхом її гомогенізації у 10 мл фізіологічного розчину. Ферментативну активність АсАТ, АлАТ, ЛДГ визначали у надосадковій рідині, що була отримана після центрифугування гомогенату. Для визначення активності ферментів застосовувались загальноприйняті методики з використанням наборів реактивів (Філісіт-Діагностика, Україна). Статистичний аналіз отриманих даних проводили з використанням $t$-критерію Стьюдента, оцінюючи вірогідність отриманих результатів на рівні значимості не менше $95 \%(p<0,05)$. Дані виражали у вигляді $M \pm m$. Достовірно відмінними вважали результати при $p<0,05$.

\section{Результати та їх обговорення}

Підвищення активності ферментів у гомогенаті тканин печінки за низкою патологій перш за все відбувається за рахунок виходу ензимів із тканин пошкодженого органа. На теперішній час існують підстави доповнити існуючі уявлення про механізми розвитку гіперферментемії за патології. Перша причина - вихід ферментів у міжклітинне середовище 3 пошкоджених ділянок органа на фоні тривалого (посиленого) біосинтезу ензимів. Тривалість гіперферментемії перш за все обумовлена тим, що вихід ферментів із пошкоджених тканин i зниження їх вмісту у клітинах стимулюють за принципом зворотного зв'язку синтез останніх. Інша причина гіперферментемії - збільшення каталітичної активності ферментів як безпосередньо у пошкодженому органі, так і за потрапляння їх у міжклітинне середовище. Існують декілька факторів, що визначають швидкість вивільнення ферментів із пошкоджених тканин: концентраційний градієнт, різний для різних ферментів і типів тканин; розмір ферментних молекул та їх відносна молекулярна маса; внутрішньоклітинна локалізація ферментів (найлегше $з$ тканин вивільняються ферменти, локалізовані у цитозолі клітин, вихід мітохондріальних ферментів можливий у випадку, коли настає розпад органели) [4]. У гепатоциті існує наступна компартменталізація ферментів: 2/3 активності АсАТ у цитозолі, 1/3 активності АсАТ у мітохондріях; АлАТ і ЛДГ - ци- 
тозольні ферменти. Цим ферментам притаманні внутрішньоклітинні каталітичні ефекти i вони найбільш діагностично важливі. У фізіологічних умовах активність указаних ферментів у міжклітинному середовищі низька, а за умов пошкодження печінки - зростає. Основні патологічні процеси у печінці об'єднують у лабораторні синдроми з урахуванням індикаторних тестів: цитолізу, холестазу, гепатодепресії, запалення, шунтування печінки, регенерації. Синдром цитолізу зустрічається за лікарських пошкоджень печінки, хронічних активних гепатитів, цирозів. Під час цього синдрому відбувається підвищення активності АсАТ, АлАТ, ЛДГ. Співвідношення величин АсАТ/АлАТ (коефіцієнт де Рітіса) вказує на природу пошкодження гепатоцитів. Гепатоцит містить більше АсAТ, ніж АлАТ, але перший фермент міститься і в цитозолі, і в мітохондріях, а другий - лише в цитозолі. За патології з пошкодженням клітинних мембран із розвитком гіперферментемії, у міжклітинний простір потрапляє більше плазматичних ензимів. Тому активність АлАТ буде вищою за АсАТ і коефіцієнт де Рітіса стає меншим 1.

Для оцінки ступеня тяжкості хронічного гепатиту використовуються такі дані активності АлАТ: 1) м'який перебіг процесу - активність ензиму менше 3 норм; 2) за помірного - вона підвищується від 3 до 10 норм; 3) за важкого - більше 10 норм. За гострого гепатиту активність ЛДГ у міжклітинному просторі зростає. Це гліколітичний цитозольний цинкумісний фермент, що зворотно каталізує окиснення лактату у піровиноградну кислоту. За синдрому холестазу, що супроводжується пошкодженням гепатоцитів, відбувається підвищення активності АлАТ і АсАТ. За некрозів гепатоцитів відбувається підвищення активності АлАТ і АсAТ, якщо некрози відсутні або низька активність процесу, - активність АсАТ і АлАТ у нормі. За хронічно активного гепатиту активність АсАТ підвищується, АлАТ - помірно збільшується, ЛДГ - підвищується. За жирової дистрофії печінки активність АсАТ і АлАТ - знижується, ЛДГ - норма. За цирозу печінки активність АсАТ помірно збільшується, АлАТ - збільшується, ЛДГ - норма [4].

Встановлено, що розвиток карциноми Герена в експериментальних тварин (група 2) супроводжується підвищенням активності всіх трьох ферментів порівняно 3 контролем (група 1), що може свідчити про порушення цілісності плазматичних мембран гепатоцитів і вивільнення в міжклітинний простір цитозольних ферментів (рис. 1, 2).

Коефіцієнт де Рітіса, що у нормі становить 1,21, складає 1,09 і вказує на м'який перебіг цитолізу гепатоцитів. Гістологічні дослідження показали, що центральні відділи дольок мають дещо атрофічні гепатоцити. Простори Діссе розширені, заповнені набряковою рідиною. У гепатоцитах спостерігається зерниста та дрібнокрапельна жирова дистрофія. Місцями перипортально помітні неглибокі ступінчаті некрози. Склероз перипортальний, незначно виражений, запалення помірне. Під дією цис-платину (група 3), незважаючи на те, що відбувається суттєве гальмування росту пухлини, відбувається продовження зростання активності ферментів: в 1,1 раза для АсАТ, в 1,2 раза для АлАТ та ЛДГ порівняно з групою 2. Якщо порівняти групу тварин 3 з групою 1, то рівень активності ферментів ще більший, ніж у групі 2: активність АсАТ зросла в 1,6 раза, АлАТ - в 1,8 раза, ЛДГ - в 1,4 раза. Коефіцієнт де Рітіса знижується до рівня 1,06, що підкреслює гепатотоксичність цис-платину. У гістологічних зрізах спостерігається виражене венозне повнокрів'я, балкова структура збереглась не всюди. У гепатоцитах виражена зерниста дистрофія, перипортальні простори розширені та набряклі. Відмічаються дифузні гепатоцелюлярні та перипортальні ступінчато виражені некрози.

За дослідження кластерних сполук ренію з органічними лігандами як модуляторів фармакологічної дії цис-платину встановлено, що $\left[\mathrm{Re}_{2}\left(\mathrm{CH}_{3} \mathrm{COO}\right)_{4}\left(\mathrm{H}_{2} \mathrm{PO}_{4}\right)_{2}\right] \cdot 2 \mathrm{H}_{2} \mathrm{O}$ (група 4) не має модулювального ефекту на ріст пухлини і не виявляє гепатопротекторної дії (група 3). Активність ЛДГ зросла в 1,2 раза, а коефіцієнт де Рітіса знизився до 
0,35. У даному випадку масивне підвищення активності АлАТ свідчить про гострий некроз гепатоцитів, який може бути викликаний дослідженими препаратами. Із боку гістологічного дослідження видно, що субкапсулярно в гепатоцитах гідропічна дистрофія. Центральні вени розширені, портальні вени різко повнокровні, в їх зонах знайдені часті осередки ступінчатих некрозів на глибину 1-3 клітин, субкапсулярний помірно та слабко виражений склероз. Отже, заміна ізобутиратних лігандів ацетатними, а хлоридних - фосфатними не призводить до стабілізації мембран гепатоцитів.

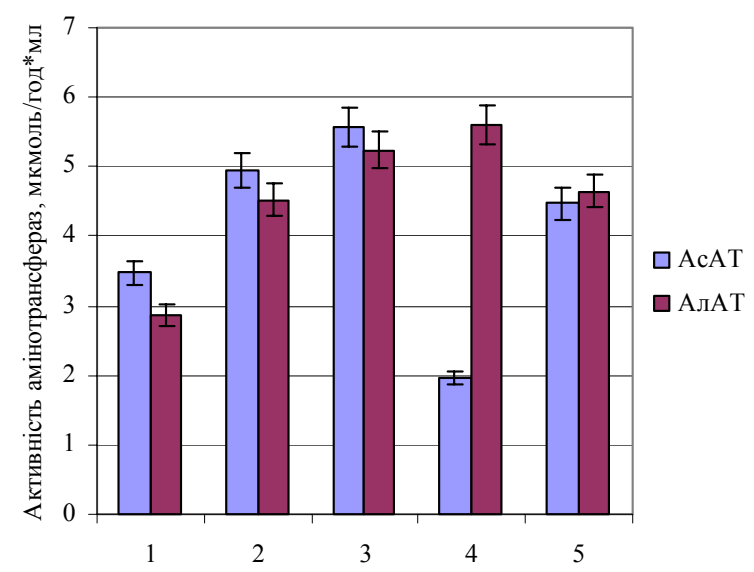

Рис. 1. Активність АсАТ і АлАТ гепатоцитів щурів: 1 - контроль, 2 - пухлина, 3 - цис- $P t$, $4-\left[\mathrm{Re}_{2}\left(\mathrm{CH}_{3} \mathrm{COO}\right)_{4}\left(\mathrm{H}_{2} \mathrm{PO}_{4}\right)_{2}\right] \cdot 2 \mathrm{H}_{2} \mathrm{O}, 5$ - ліпосомна форма $\mathrm{Re}_{2}\left(\mathrm{i}-\mathrm{C}_{3} \mathrm{H}_{7} \mathrm{COO}\right) 4 \mathrm{Cl}_{2}$

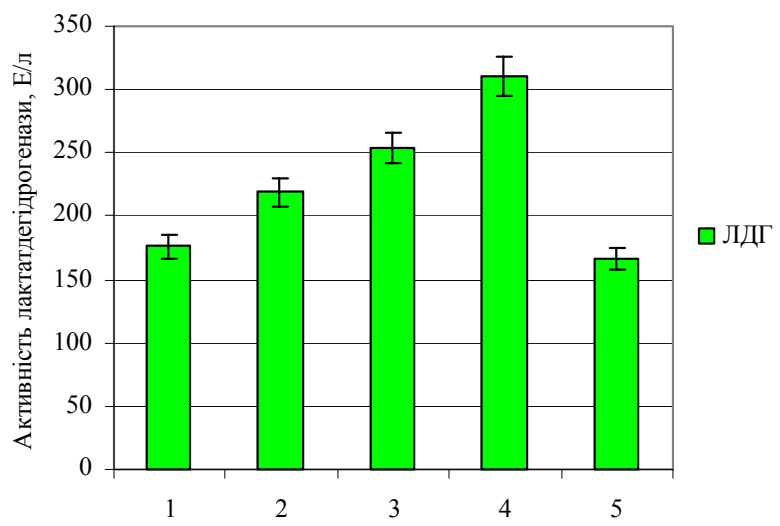

Рис. 2. Активність ЛДГ гепатоцитів щурів: 1 - контроль, 2 - пухлина, 3 - цис- $P$, $4-\left[\mathrm{Re}_{2}\left(\mathrm{CH}_{3} \mathrm{COO}\right)_{4}\left(\mathrm{H}_{2} \mathrm{PO}_{4}\right)_{2}\right] \cdot 2 \mathrm{H}_{2} \mathrm{O}, 5$-ліпосомна форма $\mathrm{Re}_{2}\left(i-\mathrm{C}_{3} \mathrm{H}_{7} \mathrm{COO}\right) 4 \mathrm{Cl}_{2}$

У групі 5 , де використано сполуку ренію 3 тетраізобутиратним лігандом у ліпосомній формі, спостерігалась висока гальмівна активність щодо росту карциноми. Використання ліпосомної форми (група 5) призвело до зниження активності ферментів порівняно з групою 3 (АсАТ - в 1,2 раза, АлАТ - в 1,1 раза і ЛДГ - в 1,5 раза), що свідчить про гепатопротекторні властивості даної форми при використанні цис-платину. Коефіцієнт де Рітіса у групі 5 підвищується до рівня 0,96, що свідчить про позитивні тенденції до поліпшення функціонального стану гепатоцитів. При цьому структура печінки достатньо диференційована, збережена балкова та дольова структура печінки. Відмічаються залишкові, слабко виражені запалення та поодинокі некротичні клітини. 


\section{Висновки}

Порівнюючи активність ферментів за канцерогенезу (група 2) з їх активністю за введення ліпосомної форми сполуки ренію (група 5), можна зробити висновок, що чутливими виявилися АсАТ і ЛДГ, активність яких знизилася, і навпаки, нечутливим $\epsilon$ АлАТ, активність якого незначно підвищилася. Отримані результати свідчать про позитивний модулювальний вплив ліпосомної форми $\mathrm{Re}_{2}\left(\mathrm{i}-\mathrm{C}_{3} \mathrm{H}_{7} \mathrm{COO}\right)_{4} \mathrm{Cl}_{2}$ на фармакологічний ефект цис-платину та гальмування розвитку карциноми Герена. Можна припустити, що ліпосомна форма більш біодоступна для клітин печінки. Таким чином, кластерні сполуки ренію поряд з антигемолітичними та протипухлинними властивостями мають гепатопротекторні функції та запобігають руйнації клітин, як відповіді на оксидативний стрес, що виникає за канцерогенезу.

\section{Бібліографічні посилання}

1. Антиоксидантні властивості кластерних комплексів ренію з деякими похідними масляної кислоти у плазмі крові та еритроцитах / Ю. П. Гриневич, С. А. Олійник, Н. І. Штеменко, О. В. Штеменко // Укр. біохім. журн. - 2003. - Т. 75, № 1. - С. 65-71.

2. Волкова О. В. Основы гистологии с гистологической техникой / О.В.Волкова, Ю. К. Елецкий. - М.: Медицина, 1971. - 272 с.

3. Изучение влияния комплексов рения с органическими лигандами на кислотную резистентность эритроцитов человека / Н. И. Штеменко, И. В. Пирожкова-Паталах, А. В. Штеменко и др. // Укр. біохім. журн. - 2000. - Т. 72, № 3. - С. 77-81.

4. Комаров Ф. И. Биохимические исследования в клинике / Ф. И. Комаров, Б. Ф. Коровкин, В. В. Меньшиков. - Элиста: Джангар, 1999. - 250 с.

5. Соляник Г. И. Противоопухолевая терапия. Вспомогательная информация / Г. И. Соляник, Г. И. Кулик. - К.: Геопринт, 1999. - 339 с.

6. Штеменко Н. І. Антирадикальна та антигемолітична активність кластерних сполук ренію 3 органічними лігандами // Укр. біохім. журн. - 2002. - Т. 74, № 46 (дод. 2). - С. 17.

7. A novel combination of cysplatin, irinotecan, and capecitabine in patients with advanced cancer / M. Jefford, M. Michael, M. A. Rosenthal et al. // Invest. New Drags. - 2001. - Vol. 22, N 2. - P. 185-192.

8. Acute hepatoxicity with intermediate-dose methotrexate in children with leukemia and nonHodgkin's lymphoma / P. Exadaktylos, T. Reiss, R. Schobess et al. // Klin. Pediatr. - 1994. Vol. 206, N 4. - P. 315-318.

9. Cersosimo R. J. Hepatotoxicity associated with cysplatin chemotherapy // Ann. Pharmacother. 1993. - Vol. 27, N 4. - P. 438-441.

10. Hematological side-effect profiles of individualized chemotherapy / M. Breidenbach, D. T. Rein, T. Schondorf et al. // Anticancer Drags. - 2003. - Vol. 14, N 5. - P. 341-346.

11. Kintzel P. E. Anticancer drag-induced kidney disorders // Drag Saf. - 2001. - Vol. 24. - P. 19-38.

12. Laidlaw S. T. Fatal hepatoxicity associated with 6-mercaptopurine therapy / S. T. Laidlaw, J. T. Reilly, S. K. Suarna // Postgrad. Med. J. - 1995. - Vol. 71, N 849. - P. 639.

13. Nephrotoxicity of platinum complexes is related to basolateral organic cation transport / T. Ludwig, C. Riethmuller, M. Gekle et al. // Kidney Int. - 2004. - Vol. 66, N 1. - P. 196-202.

14. Phase 2 trial of prolonged administration of oral topotecan in platinum/taxanerefractory ovarian, fallopian tube, and primary peritoneal cancers / M. Markman, K. Webster, K. Zanotti et al. // Gynecol. Oncol. - 2004. - Vol. 95, N 1. - P. 109-113.

15. Schimmel K. J. Cardiotoxicity of cytotoxic drugs / K. J. Schimmel, D. J. Richel, H. J. Guchelaar // Cancer Treat. Rev. - 2004. - Vol. 30, N 2. - P. 181-191.

16. Shtemenko N. Dichlorotetra- $\mu$-isobutyratodirhenium (III): enhancement of cisplatin action and RBC-stabilizing properties / N. Shtemenko, P. Collery, A. Shtemenko // Anticancer Research. 2007. - Vol. 27. - P. 2487-2492.

17. Taylor S. K. Erythropoetine (Erh-ipo) more than treatment of anemia in cancer and hemotherapy? // Medical Hypothesis. - 2003. - Vol. 60, N 1. - P. 89-93.

Надійшла до редколегії 30.10.2007 